\title{
Diameter growth rates of tawa (Beilschmiedia tawa) across the middle North Island, New Zealand - implications for sustainable forest management
}

\author{
Mark C Smale ${ }^{2 *}$, Sarah J Richardson ${ }^{1}$ and Jennifer M Hurst ${ }^{1}$
}

\begin{abstract}
Background: Tawa (Beilschmiedia tawa (A. Cunn.) Kirk) remains a minor but significant hardwood timber in New Zealand, currently sourced from tawa-dominant forest on freehold and Maori land where selective harvesting under sustainable management plans is permitted. Sustainable management plans require reliable tree growth estimates, which are used to calculate annual volume increment and harvest levels. The aims of this study were to model the relationship between diameter growth rate and tree size using existing data, and to determine the influences of within-stand competition, local climate and soil parent material on growth rates.
\end{abstract}

Methods: A dataset was compiled on the diameter growth rates of nearly 1800 trees from a wide range of published and unpublished sources for the middle North Island. Non-linear quantile regressions were used to model average growth and growth of the fastest $25 \%$ of stems, termed rapid growth.

Results: Across the middle North Island, average growth of a $400 \mathrm{~mm} \mathrm{DBH}$ (diameter at breast height) tree was $1.8 \mathrm{~mm}$ year $^{-1}$ and rapid growth was $2.8 \mathrm{~mm}_{\text {year }}{ }^{-1}$. Overall, the model accounted for $12 \%$ of the total variation in growth rate. The effect of size on diameter growth rate was modest but positive. Within-stand competition reduced tawa diameter growth rates, particularly when basal area exceeded $100 \mathrm{~m}^{2} \mathrm{ha}^{-1}$. Also, climate (winter minimum temperature and annual vapour pressure deficit) had little influence on growth rates and explained $<2 \%$ of total variation in stem growth. Soil parent material strongly influenced tawa growth rates and explained $>10 \%$ of variation in stem growth. The fastest growth rates were on soils derived from Tertiary mudstone in inland Taranaki.

Conclusions: Most of the existing data on growth rates of tawa are for trees growing on volcanic substrates. This means that the markedly faster growth on some sedimentary rather than volcanic substrates suggests that growth rates and volume increment may be underestimated for many sites in the middle North Island beyond the Volcanic Plateau. A growth dataset more representative of the range of substrates occupied by tawa is needed for management plans elsewhere in the North Island.

Keywords: Tawa; Beilschmiedia tawa; Individual growth model; Competition; Soil parent material

\section{Background}

Indigenous forests provided virtually all of the country's timber needs until 1959, after which exotic plantationgrown conifers were the main source of timber (New Zealand Forest Service, 1975). Sustained-yield management of indigenous forest was implemented in some State Forests from 1975 (New Zealand Forest Service,

\footnotetext{
* Correspondence: smalem@landcareresearch.co.nz

${ }^{2}$ Landcare Research New Zealand, Private Bag 3127, Hamilton 3240, New Zealand

Full list of author information is available at the end of the article
}

1977) in response to growing public dissatisfaction with forest clearance and an increasing national awareness of the heritage values of indigenous forest. It largely ended in 1984 with a government decision to halt harvesting in almost all indigenous forests in Crown tenure.

The demand for high-quality indigenous timber persisted, which together with a growing recognition that timber supply and the maintenance of ecological integrity need not be mutually exclusive, led to the Forests Amendment Act 1993. This Act allows the continuing harvest of significant volumes of indigenous timber on 
freehold land under a 'sustainable forest management plan' approved by the Ministry of Primary Industries, setting annual or periodic timber harvest 'at a rate matching the forest's productivity and retaining its natural values and ability to continue to provide a full range of products and amenities in perpetuity' (Ministry of Forestry, 1997). Some 116,000 ha of tawa-dominant forest is potentially available for sustainable management (Ministry of Primary Industries, unpubl. data).

In the past, tawa (Beilschmiedia tawa (A.Cunn.) Kirk) was an important hardwood timber and source of pulp fibre for high-grade paper and there is a small continuing demand for specialty uses such as flooring and interior joinery.

Tawa occurs from Northland to the northern South Island of New Zealand, and remains a significant source of hardwood timber in New Zealand. However, it is only important commercially across the middle North Island where it dominates large tracts of indigenous forest and is the subject of sustained-yield management plans approved by the Ministry for Primary Industries. Current legislation (Forests Amendment Act 1993) dictates that tawa can only be exploited by small group or individual tree harvesting. Selective harvesting of tawa may be of interest to forest owners wishing to restore coniferbroadleaved forests by offering the opportunity for some immediate revenue that can support restoration and potentially aid conifer regeneration (Carswell et al. 2007).

Sustainable management for timber production requires reliable tree growth estimates, which are used to calculate annual volume increment and harvest levels. Estimations of volume increment need to incorporate the effects of tree size, within-stand competition, and local environment, as these factors have been shown to influence the growth of tree species (Kunstler et al. 2011; Baribault et al. 2012). A lack of published growth models for indigenous New Zealand forest species means that the sustainable management of these species are difficult to achieve at present. Growth rates for tawa were last summarised by Smale et al. (1986), and there is a need to update this review to incorporate more sites, to determine if growth may be affected by tree size, within-stand competition, climate and soil parent material, and to examine the relative importance of these factors. Also, an understanding of tawa performance on an individual-tree basis is an essential element that can be integrated into stand-level models (e.g., Kunstler et al. 2011). Such models account for mixtures of species, ages and life history strategies. They are also complex, but essential for sustainable 'near-natural' management of indigenous forests.

This study provides improved growth models for tawa that incorporate individual tree characteristics, withinstand competition and stand characteristics, local environment and geographic location, using new and existing data from the middle North Island. This information will allow management guidelines to take account of how key factors affect growth of tawa on different sites and assist landowners in developing Sustainable Management Plans.

\section{Methods}

\section{Selection of datasets}

Permanent sample plot and increment core datasets containing tawa diameter growth data from tawa-dominant forest were selected from a broad region across the middle North Island, encompassing the Volcanic Plateau, Bay of Plenty, Poverty Bay, and inland Taranaki (Table 1). Elevations range from 160 to $820 \mathrm{~m}$ a.s.l. Soil parent materials include volcanic (rhyolitic, basaltic and andesitic) and sedimentary (old sedimentary, Tertiary non-calcareous, and recent alluvial) substrates.

Precipitation, mean annual temperature, winter minimum temperature and vapour pressure deficit were estimated for each plot from thin-plate splines fitted to meteorological data collected at local climate stations (Leathwick et al. 2002). Mean annual temperatures range from 9.5 to $13^{\circ} \mathrm{C}$. Mean annual rainfall varies from 1379 to $3390 \mathrm{~mm}$ year $^{-1}$.

Basal area data were available for twenty, $20 \times 20 \mathrm{~m}$ permanent plots held in the National Vegetation Survey (NVS) databank (https://nvs.landcareresearch.co.nz). For these plots only, the effect of plot-level basal area was incorporated into the size-specific growth model (from Hurst et al. 2007).

\section{Data preparation}

A total of 1826 trees was checked for errors following the methods of Hurst et al. (2007). Annual growth rate was calculated by subtracting the initial diameter at breast height $1.4 \mathrm{~m}$ above ground $(\mathrm{DBH})$ from the final diameter, then dividing by the measurement period (years). For increment core data, the mean radial increment was doubled to derive diameter increment and divided by the number of growth rings (to be equal to the number of years: Ogden \& West, 1981) to derive periodic mean annual growth rate. Only stems that were $\geq 100 \mathrm{~mm}$ $\mathrm{DBH}$ at the start of monitoring were included in the analysis resulting in the exclusion of 95 stems. Trees with a negative growth rate $>2 \mathrm{~mm} \mathrm{year}^{-1}$ or with a positive growth rate $>15 \mathrm{~mm}_{\text {year }}{ }^{-1}$ were removed from the dataset resulting in the exclusion of a further 9 stems. In all, 104 stems were removed (5.7\% of the original data set) resulting in the 1722 stems that were used in the analyses.

\section{Data analysis}

There were differences among study sites in terms of the variables measured or derived (tree, stand or site 
Table 1 Number of tawa trees sampled by each dataset and the soil parent materials for those stems

\begin{tabular}{|c|c|c|c|c|c|c|c|}
\hline \multicolumn{2}{|l|}{ Dataset } & \multicolumn{6}{|l|}{ Soil type } \\
\hline \multirow[t]{2}{*}{ Area(s) } & \multirow[t]{2}{*}{ Data type and source } & \multicolumn{3}{|l|}{ Volcanic } & \multicolumn{3}{|c|}{ Sedimentary } \\
\hline & & Rhyolite & Basalt & Andesite & Old & $\begin{array}{l}\text { Tertiary, } \\
\text { non-calcareous }\end{array}$ & Alluvium \\
\hline $\begin{array}{l}\text { Rotoehu, Mamaku, Whirinaki, Urewera, } \\
\text { Waioeka, Kaimanawa, west Taupo }\end{array}$ & Plots $^{1}$ & 541 & & & & & \\
\hline Pureora & Plots $^{2}$ & 336 & & & 110 & & \\
\hline Maungahaumi & Cores $^{3}$ & 178 & & & 43 & & \\
\hline Pureora & Plots $^{4}$ & 152 & & & & & \\
\hline central Mamaku & Plots $^{5}$ & 82 & & & & & \\
\hline Horohoro & Cores $^{6}$ & 8 & & & & & \\
\hline Rotorua Lakes & Plots $^{2}$ & & 186 & & & & \\
\hline Kaimai & Plots $^{2}$ & & & 30 & & & \\
\hline Taranaki & Plots $^{2}$ & & & 17 & & & 3 \\
\hline Matiere & Cores $^{7}$ & & & & & 92 & \\
\hline TOTAL & & 1297 & 186 & 47 & 153 & 92 & 3 \\
\hline
\end{tabular}

${ }^{1}$ Richardson et al. (2009); ${ }^{2}$ Husheer (2007); ${ }^{3}$ Smale et al. (2009); ${ }^{4}$ Smale \& Beveridge (2007); ${ }^{5}$ Smale (1981); ${ }^{6}$ Smale et al. (1997); ${ }^{7}$ Svavarsdóttir et al. (1999).

related). Consequently, only tree diameter and annual growth rate were available for all sites, and these parameters formed the basis of the analysis undertaken.

Quantile regression was used to summarise the relationship between tree growth rate $\left(\mathrm{mm} \mathrm{year}^{-1}\right)$ and tree size (DBH), consistent with Hurst et al. (2007). Quantile regression is a technique that can accommodate highly variable tree growth data (Cade \& Noon, 2003). The other strength of this approach is that regression lines can be fitted through the median or 'average' of the data (the 0.50 quantile) and any other quantile of the data, which is useful in modelling both average and aboveaverage growth.

Following Hurst et al. (2007), two growth curves were calculated and presented, average tree growth rate and rapid tree growth rate. Average tree growth rate is the fitted line through the median of the dataset (the 0.50 quantile). Rapid tree growth rate is the fitted line through the upper $50 \%$ of the dataset (the 0.75 quantile).

Plot-level estimates of climate (winter minimum temperature and annual vapour pressure deficit) and soil parent material type were used to estimate the amount of variation in tawa tree growth that can be explained by tree size, climate, and soil parent material. Mean annual temperature and precipitation were not used in these models as they were strongly correlated with winter minimum temperature and annual vapour pressure deficit, respectively, and did not contribute unique explanatory power to the models. This was achieved using non-linear least squares regression. All analyses were completed using the statistical software package R v. 2.9 (R Development Core Team 2009).
Large tawa trees are uncommon in natural forests (Smale et al. 1986) and it is difficult to estimate growth rates accurately for them. However, all available larger individuals were included in all the models tested. Each modelled relationship shows the tree size above which confidence in the model is limited. This limit is the 95th percentile of the tree diameters in each species per model (after Hurst et al. 2007; i.e., just $5 \%$ of data points fall in this diameter region). Fitted lines above this percentile are expected to have low precision.

\section{Results and discussion}

Average growth of a mature tree with a DBH of $400 \mathrm{~mm}$ was $1.8 \mathrm{~mm}_{\text {year }}^{-1}$ and rapid growth was $2.8 \mathrm{~mm}_{\text {year }}{ }^{-1}$ across the whole dataset, (1722 tawa trees) (Figure 1a). Growth was strongly influenced by basal area, i.e., within-stand competition, in the pooled NVS plot data (Figure 1b). A $400 \mathrm{~mm}$ tree achieved average growth of $2.4 \mathrm{~mm} \mathrm{yr}^{-1}$ at low basal area $\left(40 \mathrm{~m}^{2} \mathrm{ha}^{-1}\right)$, yet this was reduced to as little as $1.3 \mathrm{~mm} \mathrm{yr}^{-1}$ under high basal area (120 $\mathrm{m}^{2} \mathrm{ha}^{-1}$; Figure 1b). Smale \& Kimberley (1981) found that within-stand competition explained 15\% of the variation in tawa growth rate in a 19 year study of the trees in the 1961 selective harvesting trial at north Pureora, Volcanic Plateau. The effect of size on diameter growth rate of tawa was modest but positive, reaching almost $3 \mathrm{~mm} \mathrm{yr}^{-1}$ at the lowest basal area class.

Most of the measured trees were on soils derived from volcanic substrates, especially rhyolite but there was still sufficient replication for analysis within soil parent material for all categories (i.e., rhyolite, basalt, andesite, old sedimentary, Tertiary non-calcareous sedimentary) 


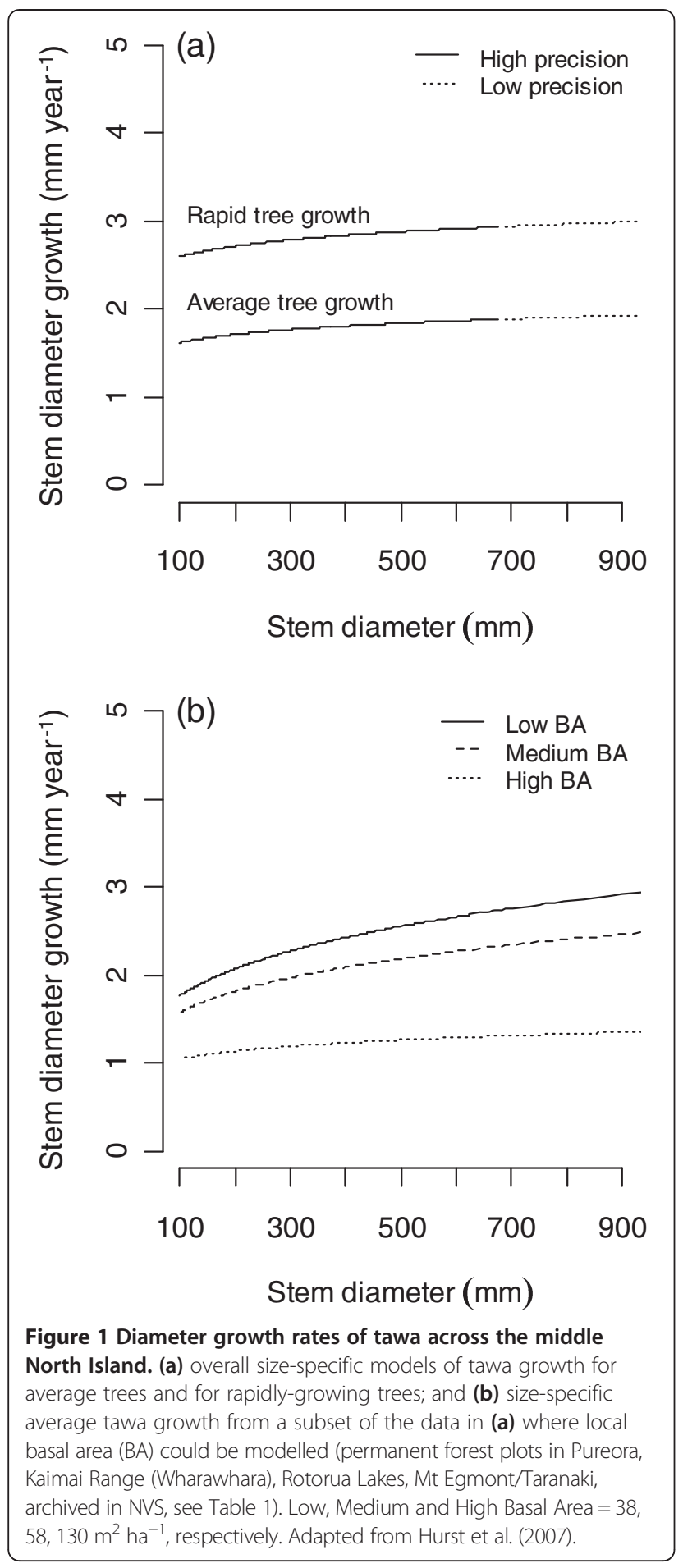

apart from alluvium ( $\mathrm{N}=3$ trees). There were only modest differences in growth rates among volcanic soil parent material types, but significantly faster growth on soils derived from non-calcareous Tertiary sedimentary rock (mudstone) at Matiere, inland Taranaki (Figure 2). Soil parent materials differ widely in their inherent fertility and in those of the soils they generate (Molloy \& Christie, 1988). In general, chemical fertility rankings of soils from these parent materials follow the ranking: basalt $>$ andesite $>$ Tertiary non-calcareous sedimentary $>$ rhyolite $>$ old sedimentary (M. McLeod, pers. com.), so the above results are somewhat unexpected.

Four models were tested to ascertain how much variation in growth was accounted for by size and soil parent material type. Given the above result that most soil parent materials - apart from Tertiary sedimentary have the same effect on tawa, these models were tested only for a difference between Tertiary sedimentary and all other geologies combined. While the model accounted for only $12 \%$ of the total variation in growth rate, the largest contributory factor tested was soil parent material. This factor accounted for most (10\%) of the variation and only $2 \%$ was accounted for by either tree size or climate (Table 2). Other variables such as crown position (Villegas et al. 2009) that were not tested here also contribute to variation in growth rate.

The non-linear quantile regression growth model (diameter increment $=\mathrm{a} \times \mathrm{DBH}^{\mathrm{b}}$, where $\mathrm{a}$ and $\mathrm{b}$ are modelled coefficients) for tawa for average diameter growth is:

$$
\begin{aligned}
& \text { Diameter increment }\left(\mathrm{mm} \mathrm{yr}^{-1}\right) \\
& \quad=1.36 \pm 0.20 \times \mathrm{DBH}^{0.08 \pm 0.04}
\end{aligned}
$$

and for rapid diameter growth;

$$
\begin{aligned}
& \text { Diameter increment }\left(\mathrm{mm} \mathrm{yr}^{-1}\right) \\
& \quad=2.24 \pm 0.32 \times \mathrm{DBH}^{0.06 \pm 0.04}
\end{aligned}
$$

Using the subset of data from the twenty permanent sample plots in which the total basal area for the plots can be determined, the model for average diameter growth using initial DBH and basal area is:

$$
\begin{aligned}
& \text { Diameter increment }\left(\mathrm{mm} \mathrm{yr}^{-1}\right) \\
& =1.68 \pm 0.25 \times \mathrm{DBH}^{0.12 \pm 0.04} \\
& \quad+\text { SumBasalArea } \times-0.0092 \pm 0.0009
\end{aligned}
$$

and for rapid diameter growth:

$$
\begin{aligned}
& \text { Diameter increment }\left(\mathrm{mm} \mathrm{yr}^{-1}\right) \\
& =2.32 \pm 0.25 \times \mathrm{DBH}^{0.16 \pm 0.03} \\
& \quad+\text { SumBasalArea } \times-0.0143 \pm 0.0015
\end{aligned}
$$

Using soil parent material and initial DBH for all stems, the model for average diameter growth on Tertiary and other sedimentary soils is:

$$
\begin{aligned}
& \text { Diameter increment }\left(\mathrm{mm} \mathrm{yr}^{-1}\right) \\
& =5.99 \pm 3.38 \times \mathrm{DBH}^{-0.13 \pm 0.15}
\end{aligned}
$$




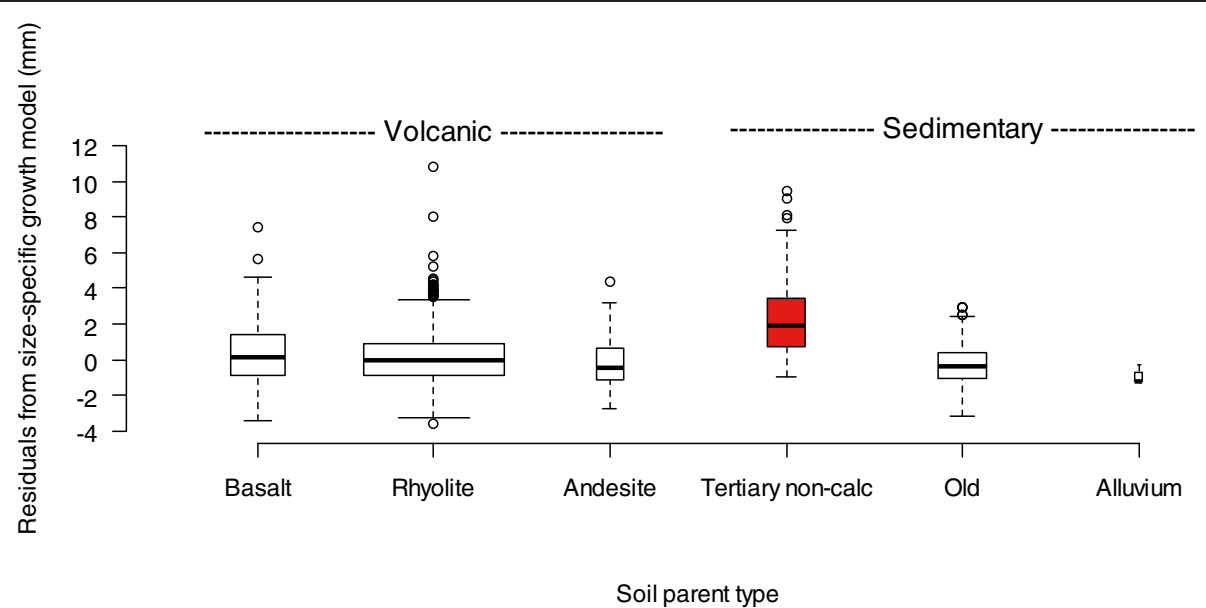

Figure 2 The effect of soil parent material on tawa stem growth rate across the middle North Island. The effect was modelled by fitting a median growth model to all tawa data (Figure 1a) and then examining how the residuals from that model varied with soil parent material. Box width is proportional to the number of observations in each soil parent material type. Basa = volcanic basalt; Rhyo = volcanic rhyolite; Ande $=$ volcanic andesite; Tert = Tertiary sedimentary; Old = older sedimentary; Allu = alluvial. Only residuals on Tertiary Sedimentary were significantly different from all others (shown in red, GLM to test for differences among means $P<0.05$ ).

and for rapid diameter growth:

$$
\begin{aligned}
& \text { Diameter increment }\left(\mathrm{mm} \mathrm{yr}^{-1}\right) \\
& \quad=7.13 \pm 4.79 \times \mathrm{DBH}^{-0.09 \pm 0.19}
\end{aligned}
$$

For tawa trees on other soils (volcanic), the model for average diameter growth is:

$$
\begin{aligned}
& \text { Diameter increment }\left(\mathrm{mm} \mathrm{yr}^{-1}\right) \\
& \quad=1.45 \pm 0.21 \times \mathrm{DBH}^{0.05 \pm 0.0 .04}
\end{aligned}
$$

and for rapid diameter growth:

$$
\begin{aligned}
& \text { Diameter increment }\left(\mathrm{mm} \mathrm{yr}^{-1}\right) \\
& \quad=2.42 \pm 0.29 \times \mathrm{DBH}^{0.03 \pm 0.04}
\end{aligned}
$$

Average diameter growth rates of tawa are somewhat slower compared with other commercially important indigenous tree species in the North Island of New Zealand. For example, the average diameter growth rate of rimu (Dacrydium cupressinum Lamb. is $2.3 \mathrm{~mm} \mathrm{yr}^{-1}$,

Table 2 Variation in tawa diameter growth rate explained (\%) by tree size, soil parent material, and climate

\begin{tabular}{ll}
\hline Model & $\begin{array}{l}\text { Variation } \\
\text { explained (\%) }\end{array}$ \\
\hline $\begin{array}{l}\text { Size + Soil parent material + Winter minimum } \\
\text { temperature + Annual Vapour Pressure Deficit }\end{array}$ & 11.7 \\
Size + Soil parent material & 10.7 \\
$\begin{array}{l}\text { Size + Winter minimum temperature + Annual Vapour } \\
\text { Pressure Deficit }\end{array}$ & 1.9 \\
Size & 0.5 \\
\hline
\end{tabular}

Variation explained is the coefficients of determination (observed growth correlated against predicted growth, squared) for models of tawa growth in the middle North Island. which is similar to those of red beech (Fuscospora fusca (Hook.f.) Heenan \& Smissen $-2 \mathrm{~mm} \mathrm{yr}^{-1}$ ) and hard beech (F. truncata (Colenso) Heenan \& Smissen $-1.7 \mathrm{~mm} \mathrm{yr}^{-1}$ ), and faster than those of silver beech (Lophozonia menziesii (Hook.f.) Heenan \& Smissen $-0.9 \mathrm{~mm} \mathrm{yr}^{-1}$ ) (Hurst et al. 2007). As with tawa, growth rates of these species vary widely among regions and with tree size and within-stand competition, However, the relative influence of soil type and climate for these species remains to be demonstrated. A recent analysis of factors affecting silver beech growth confirmed the influence of tree size and within-stand competition on the growth rates of smaller stems, but found elevation, a reflection of the physical environment and climate, more important for larger stems (Easdale et al. 2012).

\section{Conclusions}

Soil parent material may provide a simple guide to tawa diameter growth for sustainable forest management planning, with higher growth rates at the one site with Tertiary sedimentary soils. However, information on population dynamics (in terms of recruitment and mortality) as well as diameter growth rates and volume increment (dependent also on tree height and form) of existing trees is also needed for robust, long-term management plans. Data on existing tawa diameter growth rate are strongly biased towards volcanic substrates, and the markedly faster growth on some sedimentary than volcanic substrates suggests that growth rates and volume increment may be underestimated for many sites beyond the Volcanic Plateau. A tawa growth dataset more representative of the range of substrates occupied by tawa is needed for developing sustainable management plans elsewhere in the North Island. 


\section{Competing interests}

The authors declare that they have no competing interests.

\section{Authors' contributions}

MCS drafted the manuscript. SJR performed the statistical analyses. JMH compiled the dataset and assisted with data analysis. All authors read and approved the final manuscript.

\section{Acknowledgements}

We acknowledge the use of data drawn from the National Vegetation Survey Databank (NVS) and acknowledge the late Hazel Broadbent for her assistance in retrieving these data. We particularly acknowledge the following individuals for permission to use their data archived in the NVS Databank, over which they have either direct or delegated ownership: Nikki Etheridge, Andrew Grant, John Gumbley, Amy Hawcroft, Bruce Kyle, John Lyall, Donald McLean, Simon Moore, and Graham Ussher. This work was funded by the then Ministry of Agriculture and Forestry (MAF contract SUS 8906) and the then New Zealand Ministry for Science and Innovation (Indigenous Forestry programme). Alan D. Griffiths (Ministry of Primary Industries, Christchurch) organised funding for this work and commented on the draft. Dr Robert B. Allen suggested the analytical methods used and developed some of the field methods on which the paper is based. Dr. Malcolm McLeod (Landcare Research) provided advice on soil fertility. Dr. Susan Wiser, Dr. Fiona Carswell, and Larry Burrows (Landcare Research) made helpful comments on earlier drafts.

\section{Author details}

${ }^{1}$ Landcare Research New Zealand, PO Box 40, Lincoln 7640, New Zealand. ${ }^{2}$ Landcare Research New Zealand, Private Bag 3127, Hamilton 3240, New Zealand.

Received: 11 February 2013 Accepted: 31 July 2014

Published online: 25 September 2014

\section{References}

Baribault, TB, Kobe, RK, \& Finley, AO. (2012). Tropical tree growth is correlated with soil phosphorus, potassium, and calcium, though not for legumes. Ecological Monographs, 82, 189-203.

Cade, BS, \& Noon, BR. (2003). A gentle introduction to quantile regression for ecologists. Frontiers in Ecology and Environment, 1, 412-420.

Carswell, FE, Richardson, SJ, Doherty, J, Allen, RB, \& Wiser, SK. (2007). Where do conifers regenerate after selective harvest? A case study from a New Zealand conifer-angiosperm forest. Forest Ecology and Management, 253, 138-147.

Easdale, TA, Allen, RB, Peltzer, DA, \& Hurst, JM. (2012). Size-dependent growth responses to competition and environment in Nothofagus menziesii. Forest Ecology and Management, 270, 223-231.

Hurst, JM, Richardson, SJ, Wiser, SK, \& Allen, RB. (2007). Growth, mortality and recruitment of New Zealand's indigenous timber species. Lincoln: Landcare Research New Zealand. Landcare Research Contract Report LC0708/019 prepared for the Ministry of Agriculture and Forestry.

Husheer, S. (2007). Introduced red deer reduce tree regeneration in Pureora Forest, central North Island, New Zealand. New Zealand Journal of Ecology, 31, 79-87.

Kunstler, G, Albert, CH, Courbaud, B, Lavergne, S, Thuiller, W, Vieilledent, G, Zimmermann, NE, \& Coomes, DA. (2011). Effects of competition on tree radial-growth vary in importance but not in intensity along climatic gradients. Journal of Ecology, 99, 300-312.

Leathwick, JR, Morgan, F, Wilson, G, Rutledge, D, McLeod, M, \& Johnston, K. (2002). Land environments of New Zealand. A technical guide. Wellington: Ministry for the Environment.

Ministry of Forestry. (1997). Indigenous forestry: Sustainable management. A guide to plans and permits. Christchurch: Ministry of Forestry.

Molloy, LF, \& Christie, Q. (1988). Soils in the New Zealand landscape - the living mantle (p. 239). Wellington: Mallinson Rendell.

New Zealand Forest Service. (1975). Statistics of the Forests and Forest Industries of New Zealand. In New Zealand Forest Service Information Series No. 33. Wellington: Government Printer.

New Zealand Forest Service. (1977). Management policy for New Zealand's indigenous State Forests. Wellington: New Zealand Forest Service.

Ogden, J, \& West, CJ. (1981). Annual rings in Beilschmiedia tawa (Lauraceae). New Zealand Journal of Botany, 19, 397-400.
R Development Core Team. (2009). R: A language and environment for statistical computing. Vienna, Austria: R Foundation for Statistical Computing. ISBN 3-900051-07-0, URL http://www.R-project.org.

Richardson, SJ, Smale, MC, Hurst, JM, Fitzgerald, NB, Peltzer, DP, Bellingham, PJ, Allen, RB, \& McKelvey, PJ. (2009). Large-tree growth and mortality rates in forests of the central North Island, New Zealand. New Zealand Journal of Ecology, 33, 208-215.

Smale, MC, \& Beveridge, AE. (2007). Long-term ecological impacts of selective harvesting on a New Zealand conifer-hardwood forest. New Zealand Journal of Forestry Science, 37, 3-22.

Smale, MC, \& Kimberley, MO. (1981). Factors affecting growth of tawa trees in unlogged and selectively logged forest, Pureora. Rotorua: Forest Research Institute, New Zealand Forest Service. Production Forestry Division Indigenous Forest Management Report No 33.

Smale, MC. (1981). Growth and mortality of tawa in virgin and selectively logged forest, Mamaku Plateau. Rotorua: Forest Research Institute, New Zealand Forest Service. Production Forestry Division Indigenous Forest Management Report No. 32.

Smale, MC, Bathgate, JL, \& Guest, R. (1986). Current prospects for tawa. New Zealand Journal of Forestry, 31, 13-18.

Smale, MC, Burns, BR, Smale, PN, \& Whaley, PT. (1997). Dynamics of upland podocarp/broadleaved forest on Mamaku Plateau, central North Island, New Zealand. Journal of the Royal Society of New Zealand, 27, 513-532.

Smale, MC, Richardson, SJ, \& Burrows, LE. (2009). Synthesis of tawa and rimu growth rates from the middle North Island. Lincoln: Landcare Research New Zealand. Landcare Research Contract Report. LC0809/138.

Svavarsdóttir, K, Allen, RB, Burrows, LE, Coomes, DA, Wiser, SK, Smale, MC, \& Benecke, U. (1999). Silvicultural research in selected forest types: a podocarp-tawa forest in Taranaki. Lincoln: Landcare Research New Zealand. Landcare Research Contract Report LC9899/119.

Villegas, Z, Pena-Claros, M, Mostacedo, B, Alarco, A, Leano, C, Pariona, W, \& Choque, U. (2009). Silvicultural treatments enhance growth rates of future crop trees in a tropical dry forest. In Forest Ecology and Management (Vol. 258, pp. 971-977).

\section{doi:10.1186/s40490-014-0020-9}

Cite this article as: Smale et al:: Diameter growth rates of tawa (Beilschmiedia tawa) across the middle North Island, New Zealand implications for sustainable forest management. New Zealand Journal of Forestry Science 2014 44:20.

\section{Submit your manuscript to a SpringerOpen ${ }^{\circ}$ journal and benefit from:}

- Convenient online submission

- Rigorous peer review

- Immediate publication on acceptance

- Open access: articles freely available online

- High visibility within the field

- Retaining the copyright to your article

Submit your next manuscript at $>$ springeropen.com 